\title{
Synthesis of benzannelated five-membered heteroaromatic compounds from 2,4,6-trinitrotoluene
}

\author{
Maxim A. Bastrakov, Alexey M. Starosotnikov, and Svyatoslav A. Shevelev* \\ N.D. Zelinsky Institute of Organic Chemistry RAS, \\ Leninsky prospect 47, Moscow,119991, Russia \\ E-mail:shevelev@ioc.ac.ru
}

Dedicated to Professor A. F. Pozharsky on the occasion of his $70^{\text {th }}$ birthday

\begin{abstract}
Methods for the synthesis of five-membered benzannelated heterocyclic compounds from the military explosive 2,4,6-trinitrotoluene (TNT) are summarised. The general approach concerns the transformation of the TNT methyl group followed by either intramolecular substitution of the ortho-nitro group or regioselective substitution of the ortho-nitro group by an appropriate nucleophile and subsequent cyclization.
\end{abstract}

Keywords: 2,4,6-Trinitrotoluene, benzannelated five-membered heterocycles, nitro group, nucleophilic substitution, cyclization

\section{Table of Contents}

1. Introduction

2. Discussion

2.1. TNT Reactions by the methyl group

2.2. Transformations of the nitro group

2.3. Synthesis of five-membered benzannelated heterocyclic compounds

2.3.1. Synthesis of benzannelated five-membered heterocycles with one heteroatom

2.3.2. Synthesis of benzannelated five-membered heterocycles with two heteroatoms

3. References 


\section{Introduction}

2,4,6-Trinitrotoluene (TNT) is the most mass-scale military explosive. Its industrial production started at the end of the $19^{\text {th }}$ century, and during World War I TNT became a conventional explosive in the belligerent armies. TNT applications greatly extended during World War II, and its production capacity drastically built up. ${ }^{1}$ TNT has been in the focus of a great number of publications in the scientific literature. Most of these relate to the explosive characteristics of TNT and its mixtures with other compounds. Relatively fewer papers have so far directly addressed TNT chemistry, although their absolute number is quite significant. ${ }^{2}$ However, systematic researches on TNT chemical transformations have been lacking, except for the generation of stable $\sigma$-complexes through the nucleophilic addition to the TNT aromatic cycle. ${ }^{3}$ Only during the last 10-15 years, judging from a great number of publications, have comprehensive studies of TNT chemistry, focused on TNT transformations to readily available multi-purpose raw materials, been undertaken. This review discusses a single aspect of TNT transformations - the preparation of TNT-sourced dinitro benzannelated five-membered aromatic heterocycles. This has been the most closely researched area of TNT transformations until now. To avoid duplication in describing syntheses of benzannelated heterocycles the review provides the introductory sections that address TNT reactions by the methyl group and reactions involving TNT nitro groups.

Caution: polynitroaromatic compounds (TNT and products of its transformations) are explosive; proper precautions and protective equipment (shields, glasses) should be used during even smallscale experiments.

\section{Discussion}

\subsection{Reactions of the TNT methyl group}

An important TNT reaction is its oxidation. Resulting 2,4,6-trinitrobenzoic acid 2 and its functional derivatives (amides, haloanhydrides, and nitrile) are of interest as starting molecules in the synthesis of polyfunctional heteroaromatic compounds.<smiles>Cc1c([N+](=O)[O-])cc([N+](=O)[O-])cc1[N+](=O)[O-]</smiles>

1

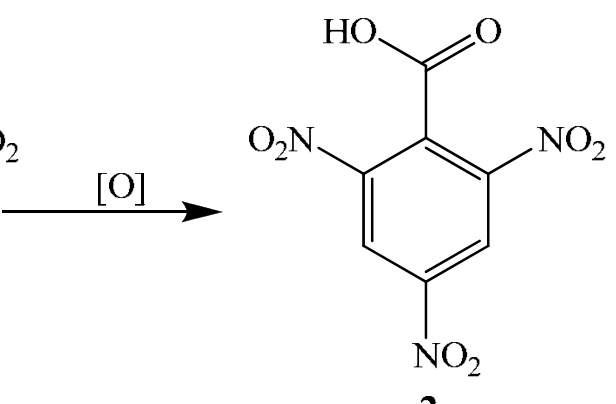

2 
It is known that 2,4,6-trinitrobenzoic acid can be prepared by TNT oxidation using various oxidants such as $\mathrm{HNO}_{3}{ }^{4 \mathrm{a}}$ and $\mathrm{Na}_{2} \mathrm{Cr}_{2} \mathrm{O}_{7}{ }^{4 \mathrm{~b}}$ as well as by electrolytic oxidation. ${ }^{4 \mathrm{c}}$ TNT oxidation by $\mathrm{K}_{2} \mathrm{Cr}_{2} \mathrm{O}_{7}$ in $\mathrm{H}_{2} \mathrm{SO}_{4}$ is a preparative technique to produce this acid. ${ }^{5}$ A process technology of TNT oxidation by nitric acid at high temperature and pressure is reported. ${ }^{6}$ The treatment of the intermediate acid with $\mathrm{SOCl}_{2}\left(\right.$ or $\left.\mathrm{PCl}_{5}\right)$ leads to respective acid chloride, and the latter reacts with aqueous ammonia solution to give 2,4,6-trinitrobenzoic acid amide. ${ }^{7}$ Another approach to preparing the amide is a reaction of 2,4,6-trinitrobenzoic acid with urea. The reaction runs in $30 \%$ oleum. ${ }^{7}$ Such method allows preparing the amide in a higher yield $(90 \%)$ than by the acid chloride treatment with $\mathrm{NH}_{3}(58 \%)$.

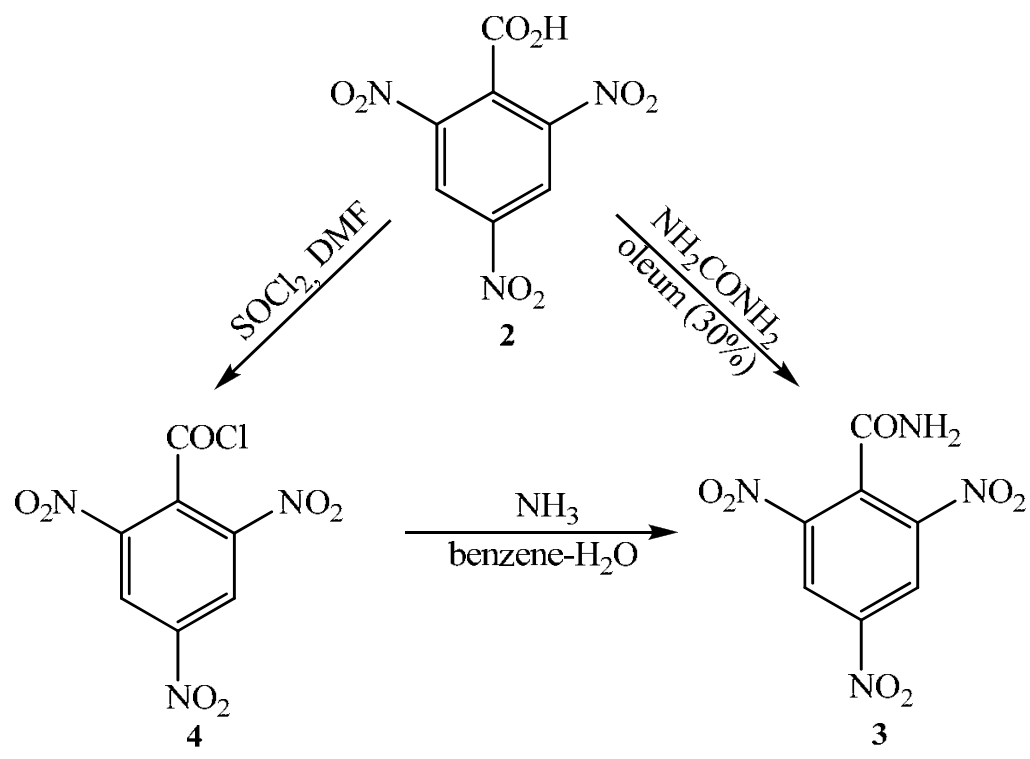

Another TNT derivative, which is no less important, is 1,3,5-trinitrobenzene (TNB). TNB is a multi-purpose synthon, including use for the synthesis of polyfunctional benzannelated heterocycles. ${ }^{8-11}$ TNB is prepared by decarboxylation of 2,4,6-trinitrobenzoic acid. ${ }^{5,12}$<smiles>Cc1c([N+](=O)[O-])cc([N+](=O)[O-])cc1[N+](=O)[O-]</smiles>

The TNT methyl group is $\mathrm{CH}$-active and able to condense with various aromatic electrophiles, predominantly in the presence of bases (TNT acidity: $\mathrm{pK}_{\mathrm{a}} \mathrm{H}_{2}=$ 13.6; $\left.\mathrm{pK}_{\mathrm{a}}{ }_{3}{ }_{3}{ }^{\mathrm{OH}}=15.6 ; \mathrm{pK}_{\mathrm{a}}{ }^{\mathrm{DMSO}}=10.5\right){ }^{13}$ 
Among the most well-known TNT reactions by the methyl group is reaction with aromatic aldehydes leading to stilbene derivatives. Ullmann and Pfeiffer were the first to study these reactions back in the early $20^{\text {th }}$ century. ${ }^{14,15}$ TNT condensation with aromatic aldehydes proceeds on refluxing the components in the benzene medium in the presence of a catalytic amount of secondary amine (piperidine, morpholine or diethylamine). In addition to benzaldehyde derivatives, their heteroaromatic analogs also react in these conditions. ${ }^{16-18}$ These stilbenes have been lately shown to be important semi-products in the 4,6-dinitroindole synthesis. ${ }^{18}$

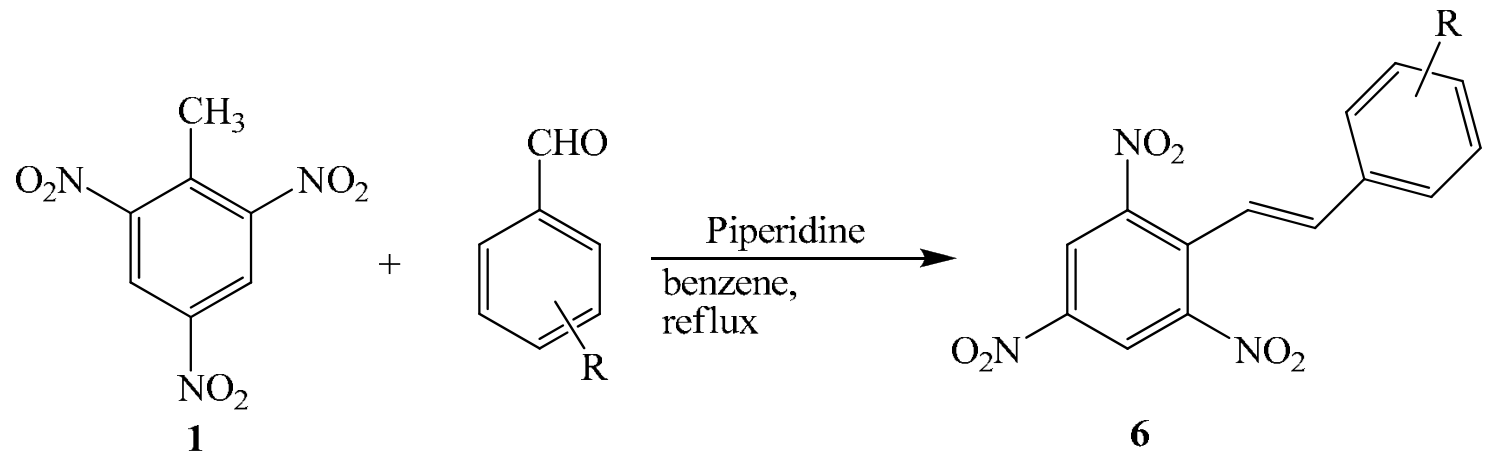

TNT reacts with aliphatic aldehydes by the aldol type to yield corresponding alcohols. Heating of TNT with formalin or in a formalin-THF mixture under reflux leads to picrylethanol in a nearly quantitative yield. ${ }^{19}$ Picrylethanol, as affected by $\mathrm{Ac}_{2} \mathrm{O}-\mathrm{HNO}_{3}$, generates nitrate 8, which under the action of $\mathrm{CH}_{3} \mathrm{CO}_{2} \mathrm{Na}$ transforms to 2,4,6-trinitrostyrene $9{ }^{20}$<smiles>C=Cc1c([N+](=O)[O-])cc([N+](=O)[O-])cc1[N+](=O)[O-]</smiles>

Also, 2,4,6-trinitrophenylethanol 7 reacts with acetic anhydride to give 2,4,6trinitrophenylethylacetate 10. The latter is a convenient starting compound for preparation of trinitrophenylacetic acid $\mathbf{1 1} .^{21}$ 
<smiles>CC(=O)OCCc1c([N+](=O)[O-])cc([N+](=O)[O-])cc1[N+](=O)[O-]</smiles>

A reaction with fluoral and chloral is another example of the TNT interaction with aliphatic aldehydes. ${ }^{22}$ The reaction runs smoothly under reflux in THF in the presence of $\mathrm{K}_{2} \mathrm{CO}_{3}$.<smiles>Cc1c([N+](=O)[O-])cc([N+](=O)[O-])cc1[N+](=O)[O-]</smiles>

$\mathrm{X}=\mathrm{F}, \mathrm{Cl}$

A TNT reaction with dimethylformamide dimethylacetal (DMF DMA) gives an opportunity to synthesize a broad variety of polynitro benzannelated heterocyclic compounds. Of note are mild conditions of the TNT reaction with DMF DMA (in toluene at $20^{\circ} \mathrm{C}$ ). ${ }^{23}$ A synthesis of 2,4,6-trinitrophenylacetaldehyde $\mathbf{1 4}$ was designed on the basis of enamine $13 .{ }^{23}$ This compound is a convenient synthon for the annelating of additional heterocyclic moieties.<smiles>Cc1c([N+](=O)[O-])cc([N+](=O)[O-])cc1[N+](=O)[O-]</smiles>

2,4,6-Trinitrobenzaldehyde is another TNT derivative with an extensive synthetic potential. The method was described for the first time by Sachs and Everding ${ }^{24}$ and was optimized 
repeatedly afterwards. ${ }^{25,26}$ TNT reacts with $p$-nitrosodialkylanilines to generate nitrones $\mathbf{1 5}$, $^{27}$ which yield 2,4,6-trinitrobenzaldehyde $\mathbf{1 6}$ in the acidic hydrolysis conditions.<smiles>[R10]Nc1ccc(N(O)/C=C/c2c([N+](=O)[O-])cc([N+](=O)[O-])cc2[N+](=O)[O-])cc1</smiles>

Note that for a long time compound $15(\mathrm{R}=\mathrm{Me})$ was assumed to have a different structure, i.e. that of azometin $\mathbf{1 5}^{\prime}{ }^{24-26,28}$ However, it has recently been established that this compound is a nitrone. The interaction of trinitrobenzaldehyde with 4 -( $N, N$-dimethylamino)aniline has been shown to lead to compound 15' that differs from a product of TNT condensation with 4-nitroso( $N, N$-dimethyl)aniline (NMR and $\mathrm{mp}$ data). ${ }^{27}$ It is known from older researches that condensation of nitrotoluenes with nitroso compounds results in $N$-oxides. ${ }^{29-31}$ A comparison of all the foresaid facts led to the conclusion that the product of TNT condensation with nitrosodimethylaniline is nitrone $\mathbf{1 5 .}$<smiles>Cc1ccc(N=Cc2c([N+](=O)[O-])cc([N+](=O)[O-])cc2[N+](=O)[O-])cc1</smiles> 
Imines, similar to compound 15', are generated in a reaction between trinitrobenzaldehyde $\mathbf{1 6}$ and aromatic amines. The reaction is performed either by boiling in benzene in the presence of $\mathrm{TsOH}$ in catalytic amounts ${ }^{28}$ or in boiling $\mathrm{MeOH}^{32}$

2,4,6-Trinitrobenzonitrile $\mathbf{1 8}$ is produced by the TNT treatment with nitrosyl chloride via the 2,4,6-trinitrobenzaldoxime as an intermediate. ${ }^{33}$<smiles>Cc1c([N+](=O)[O-])cc([N+](=O)[O-])cc1[N+](=O)[O-]</smiles>

A method of trinitrobenzonitrile synthesis from trinitrobenzaldehyde has been described. The treatment of aldehyde $\mathbf{1 6}$ with hydroxylamine hydrochloride in formic acid results in nitrile $\mathbf{1 8}{ }^{34}$<smiles>O=Cc1c([N+](=O)[O-])cc([N+](=O)[O-])cc1[N+](=O)[O-]</smiles>

16<smiles>N#Cc1c([N+](=O)[O-])cc([N+](=O)[O-])cc1[N+](=O)[O-]</smiles>

18

\subsection{Transformations of the nitro group}

Stable anion $\sigma$-complexes are normally formed under the action of $\mathrm{O}-, \mathrm{S}-, \mathrm{N}-, \mathrm{P}-$ and $\mathrm{C}$ nucleophiles and hydride ions on TNT due to nucleophilic addition to the aromatic cycle, usually to the C(3) atom. Further on, in case of considerably basic nucleophiles (alcoholates, stabilized carbanions, and amines) in a slower stage the proton splits off from the TNT methyl group and the 2,4,6-trinitrobenzyl anion is generated. 3,35 


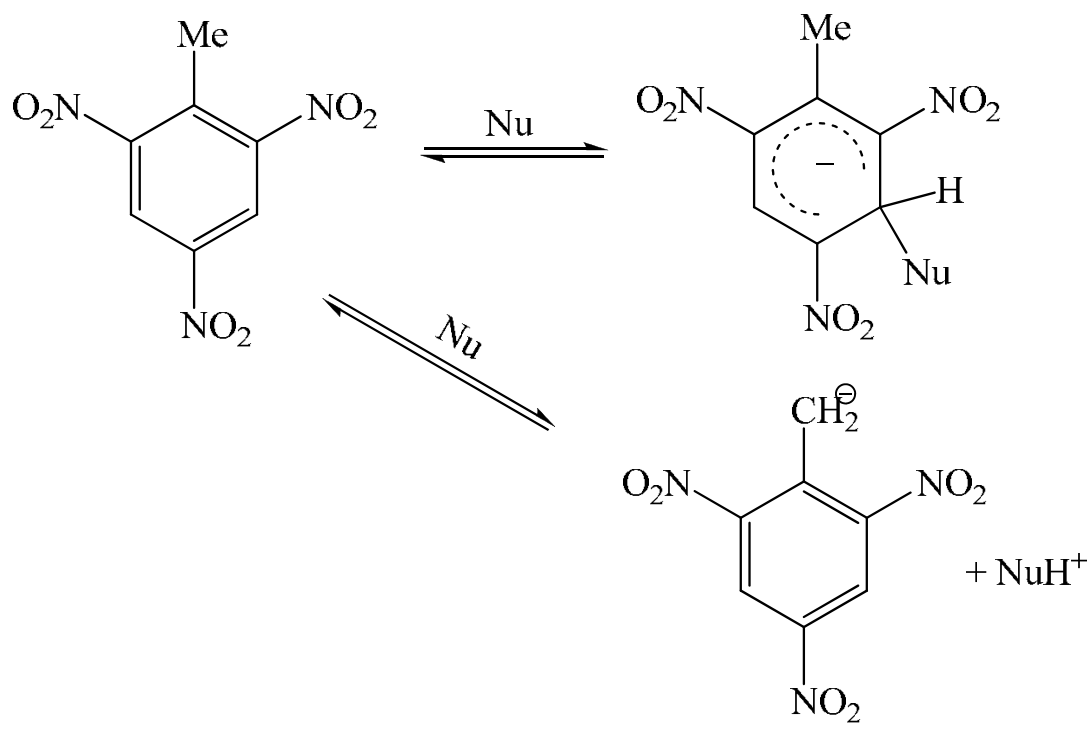

Regioselective substitution of the ortho-nitro group occurs during heating TNT with aromatic and aliphatic thiols in the presence of inorganic bases in aprotic dipolar solvents. ${ }^{6,36-38}$<smiles>[R19]c1cc([N+](=O)[O-])cc([N+](=O)[O-])c1C</smiles>

TNT derivatives with reduced nitro groups are also of interest as possible semi-products to prepare bicyclic systems. Currently there are methodologies that allow selective reduction of the nitro group in $\mathrm{TNT}^{39-42}$<smiles>Cc1c(N)cc(N)cc1N</smiles>

TNT

\subsection{Synthesis of five-membered benzannelated heterocyclic compounds}

A strategy for the synthesis of five-membered benzannelated heterocycles builds on the transformation of the 2,4,6-TNT methyl group followed by either intramolecular substitution of 
the ortho-nitro group (Variant A) or regioselective substitution of the ortho-nitro group by an appropriate nucleophile and subsequent cyclization (Variant B).<smiles>[X]c1cc([N+](=O)[O-])cc([N+](=O)[O-])c1-c1ccc(Oc2c([N+](=O)[O-])cc([N+](=O)[O-])cc2[N+](=O)[O-])c([N+](=O)[O-])c1</smiles>

"B"

A number of older publications describe synthetic approaches to some compounds on the basis of TNT derivatives, which were assumed to have a structure of 4,6-dinitrobenzannelated heterocycles. Recently after the application of advanced physical-chemical methods for the structure identification, it appears that these data needed additional verification. For instance, azometins $\mathbf{2 0}$ are known to readily react with arylamines in boiling acetic acid to give individual compounds, which were earlier assigned either the A or $\mathbf{B}$ structure. $^{43-46}$<smiles>N#[N+]c1cc([N+](=O)[O-])cc([N+](=O)[O-])c1/C=N/[Al]</smiles>

20<smiles>CC(N)(N)C(=O)O</smiles>

A<smiles>O=[N+]([O-])c1cc2c(c([N+](=O)[O-])c1)N([Al])N([Al])N2O</smiles>

B

This reaction has recently been examined in more detail. The structure of the reaction products was proved using X-ray analysis (XRA). It was established that the earlier assumptions regarding the structures $\mathbf{A}$ and $\mathbf{B}$ had been incorrect. ${ }^{47}$ The synthesized compounds proved to be $N$-aryl-2-arylazo-4,6-dinitrobenzamides. 
<smiles>O=C(N[Al])c1c(/N=N/[Al])cc([N+](=O)[O-])cc1[N+](=O)[O-]</smiles>

Another series of researches communicated at the beginning of the $20^{\text {th }}$ century deals with cyclization of azometins $\mathbf{2 0}$ to derivatives of 3-hydroxy-4,6-dinitroindazol- $N$-oxides $\mathbf{C}$. The reaction was performed in the presence of $\mathrm{Na}_{2} \mathrm{CO}_{3}$ in boiling ethanol. ${ }^{48-50}$ However, when the review's authors attempted to reproduce the methodology it appeared that the reaction conditions needed clarification.

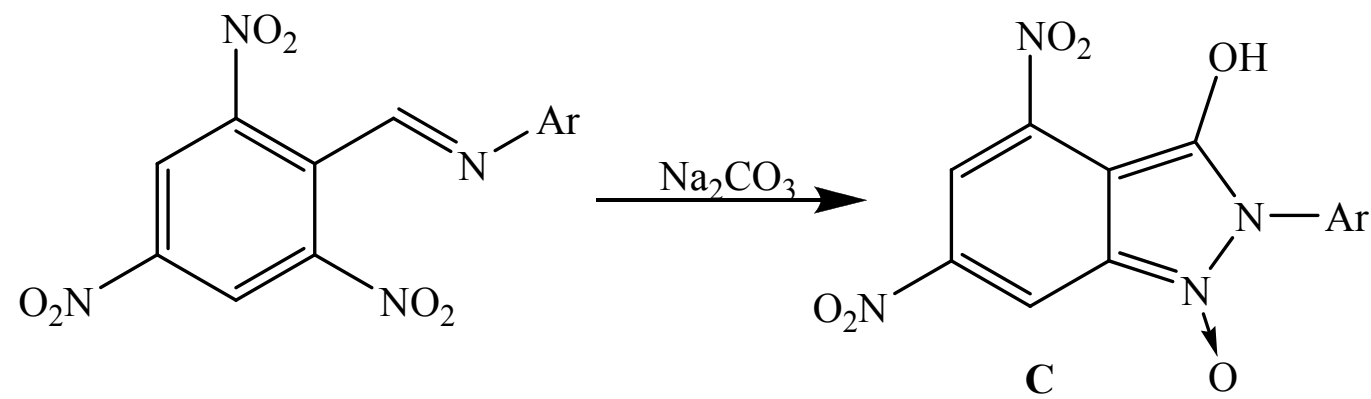

\subsubsection{Synthesis of benzannelated five-membered heterocycles with one heteroatom. A TNT-} based synthesis of earlier unavailable 2-aryl and 2-hetaryl-4,6-dinitroindoles has been developed. ${ }^{18}$ Only ortho- $\mathrm{NO}_{2}$ is substituted under the action of $\mathrm{NaN}_{3}$ in stilbenes resulting from TNT condensation with aromatic and heteroaromatic aldehydes, and azides $\mathbf{2 1}$ are generated. These upon thermolysis give indoles 22 in high yields.<smiles>Cc1c([N+](=O)[O-])cc([N+](=O)[O-])cc1[N+](=O)[O-]</smiles>

A recent paper proposes another method that allows the preparation of indoles 22 from azides 21 in an even higher yield $(>80 \%) .{ }^{51}$ The azides react with the system $\mathrm{FeCl}_{3} * 6 \mathrm{H}_{2} \mathrm{O}-\mathrm{NaI}$ in mild conditions (room temperature) to give indoles 22. 


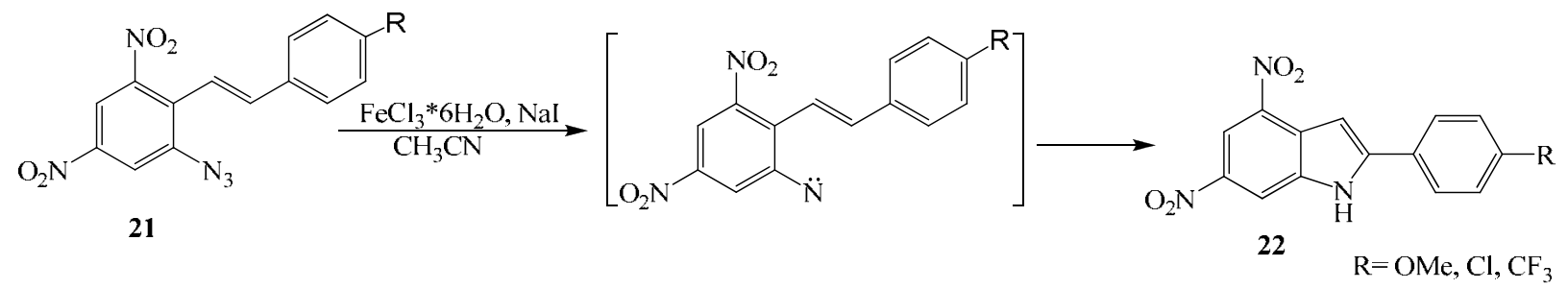

Also, the literature communicates a few approaches to the synthesis of 4-X-6-dinitroindoles (X = R-sulfonyl, 1,2,3-triazolyl). The first approach proposes to prepare 2-R-sulfonyl-4,6dinitrotoluenes through substitution of the ortho-nitro group with aromatic or aliphatic thiol and oxidation of the obtained sulfide to sulfone. ${ }^{52}$<smiles>[R5]c1cc([N+](=O)[O-])cc([N+](=O)[O-])c1C</smiles>

Sulfones $\mathbf{2 3}$ undergo condensation reaction with aromatic aldehydes. The ortho-nitro group in the formed stilbenes $\mathbf{2 4}$ is selectively substituted by the azido group, and the thermolysis of azides $\mathbf{2 5}$ leads to 2-aryl-4-(R-sulfonyl)-6-nitroindoles $\mathbf{2 6}$.

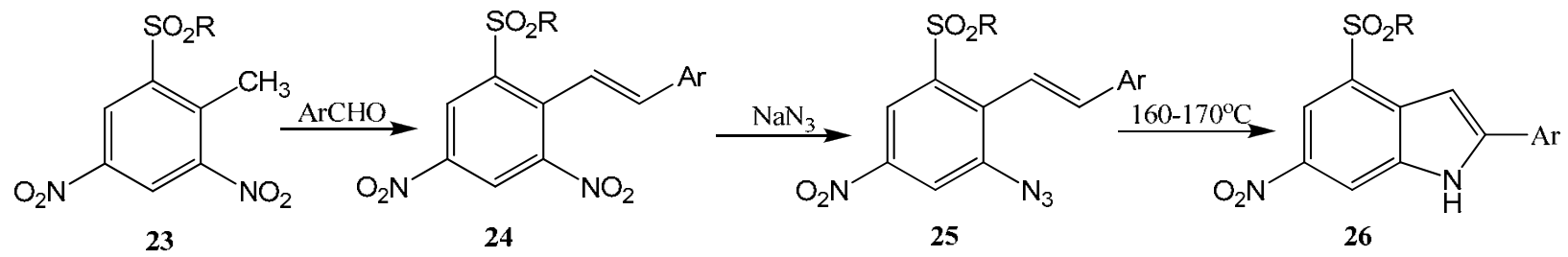

The synthesis of indoles containing a triazole moiety in position 4 suggests that 2-azido-4,6dinitrostilbenes should be used as initial molecules ${ }^{53}$ and comprises their introduction to 1,3dipolar cycloaddition, substitution of the ortho-nitro group in the obtained 2-( $N$-1,2,3-triazolyl)4,6-dinitrostilbenes for the azido group, and the thermolysis of the synthesized products. 
<smiles>CC(=O)CC(C)C(C)C(C)=O</smiles>

4,6-Dinitroindoles can also be prepared on the basis of picrylethanol. ${ }^{54,55}$ Here two approaches to the target product synthesis are possible. In the first case, ${ }^{54}$ the ortho-nitro group in the initial alcohol $\mathbf{7}$ is reduced selectively. Amino alcohol 30, when treated with $p$ toluenesulfochloride, cyclizes to 2,3-dihydro-4,6-dinitro-1-tosylindole 31. The latter is readily oxidized by air oxygen to give indole 32 .<smiles>O=[N+]([O-])c1cc([N+](=O)[O-])c(CCO)c([N+](=O)[O-])c1</smiles><smiles>CC(C)C</smiles><smiles>Nc1cc([N+](=O)[O-])cc([N+](=O)[O-])c1CCO</smiles>

30
TsCl, pyridine

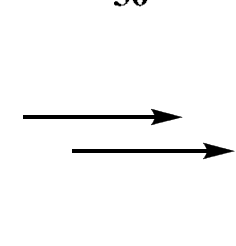

$\mathrm{O}_{2} \mathrm{~N}$

32

$\operatorname{In}^{55}$ the authors used an approach based on the picrylethanol transformation to nitrate that was readily denitrated under the action of sodium acetate to produce 2,4,6-trinitrostyrene 9 . The ortho-nitro group in the latter is selectively substituted by the azido group, and the thermolysis of azide leads to 4,6-dinitroindole 32'. 


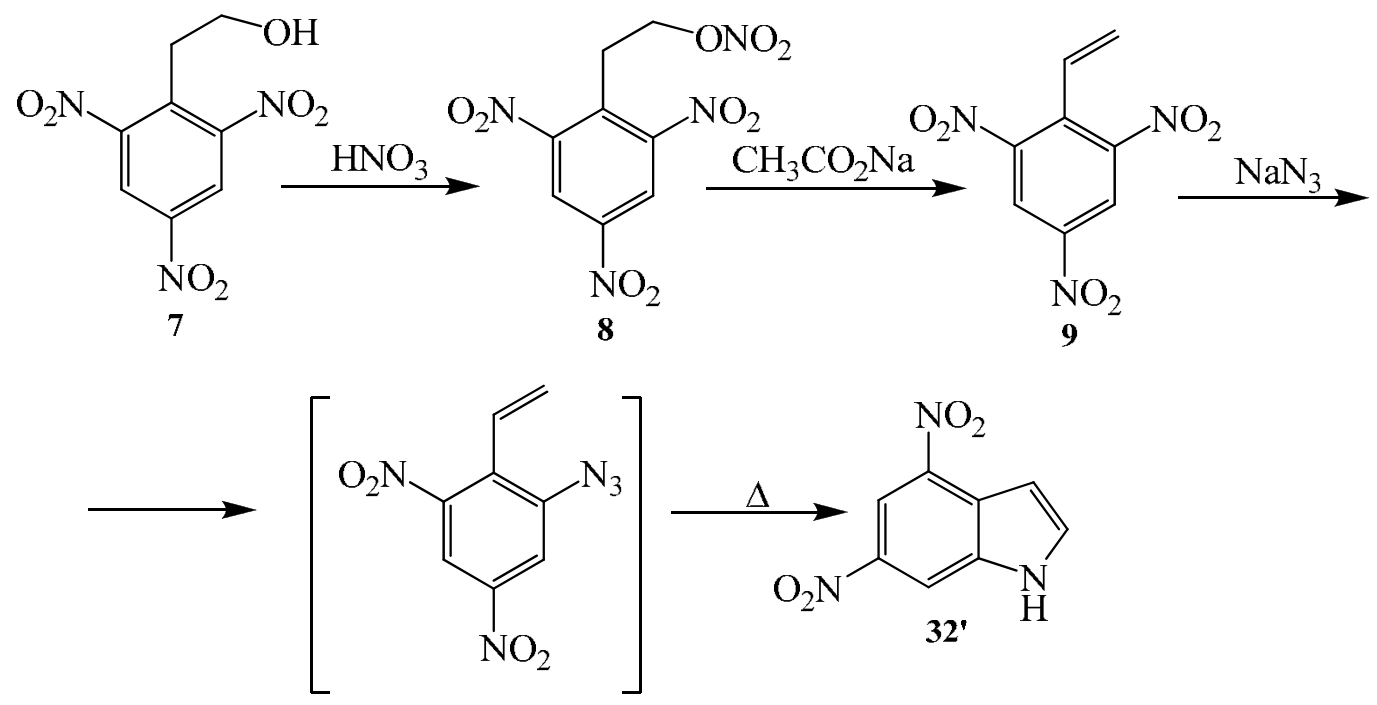

4,6-Dinitroindole can be prepared on the basis of 2-amino-4,6-dinitrotoluene through the interaction with dimethylformamide dimethylacetal. Resulting $\beta$-( $N, N$-dimethylamino)-2-amino4,6-dinitrostyrene cyclizes to 4,6-dinitroindole under the action of $\mathrm{TsOH}^{56}$<smiles>COC(Cc1c(N)cc([N+](=O)[O-])cc1[N+](=O)[O-])OCC(Oc1cc([N+](=O)[O-])c2cc(C(C)(C)OC(C)(C)C)[nH]c2c1)C(F)(F)F</smiles>

An alternative method proposed by the authors for preparing 4,6-DNI consists of ortho-nitro group reduction in picrylacetaldehyde dimethylacetal $34 .{ }^{56}$ The unexpected generation of 1-R4,6-dinitroindoles was detected in a reaction between 2,4,6-trinitrostyrene and primary amines. ${ }^{57}$ In the first step, the amine undergoes addition by the double bond yielding adduct $\mathbf{3 5}$ where intramolecular substitution of the nitro group occurs to give indoline 36. The indoline is oxidized by the nitro compounds present in the reaction mixture and indole $\mathbf{3 7}$ is produced in $12-18 \%$ yield. $^{57}$ 
<smiles>C=Cc1c([N+](=O)[O-])cc([N+](=O)[O-])cc1[N+](=O)[O-]</smiles>

9

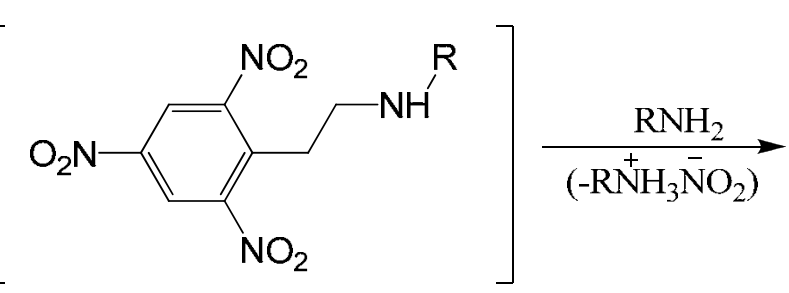

35

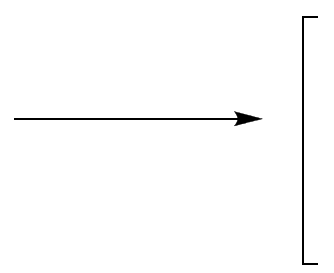

$\mathrm{R}=\mathrm{PhCH}_{2}, \mathrm{PhCH}_{2} \mathrm{CH}_{2}, \mathrm{Me}$

An interaction of trinitrobenzene with phenylacetamidines leads to 4,6-dinitroindole derivatives 38 in low yields. ${ }^{58}$ In the authors' opinion, the indole formation is preceded by nucleophilic substitution of hydrogen in TNB, and then intramolecular substitution of the orthonitro group occurs.<smiles>O=[N+]([O-])c1cc([N+](=O)[O-])cc([N+](=O)[O-])c1</smiles>

5<smiles>[R]N(C)/C(Cc1ccccc1)=N/C</smiles><smiles>[R]C(C)C(=NC)C(c1ccccc1)c1c([N+](=O)[O-])cc(C)cc1[N+](=O)[O-]</smiles><smiles>[R]C(C)c1c(-c2ccccc2)c2c([N+](=O)[O-])cc([N+](=O)[O-])cc2n1C</smiles>

A reaction of $\mathrm{N}$-arylazometins $\mathbf{2 0}$ with the methyl ester of thioglycolic acid in the presence of $\mathrm{K}_{2} \mathrm{CO}_{3}$ in acetonitrile at room temperature leads to the ortho-nitro group substitution and formation of sulfides 39. If the reaction is carried out in boiling acetonitrile, sulfides undergo intramolecular cyclization resulting in 3-arylamino-4,6-dinitrobenzo[b]thiophene-2methylcarboxylates $\mathbf{4 0}$. $^{59}$ 
<smiles>[R]c1cccc(/N=C/c2c([N+](=O)[O-])cc([N+](=O)[O-])cc2[N+](=O)[O-])c1</smiles>

20

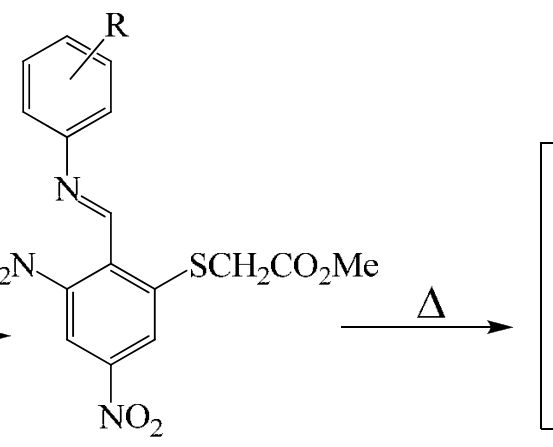

39<smiles>[R]c1ccc(NC2c3c(cc([N+](=O)[O-])cc3[N+](=O)[O-])SC2C(C)=O)cc1</smiles>

40a

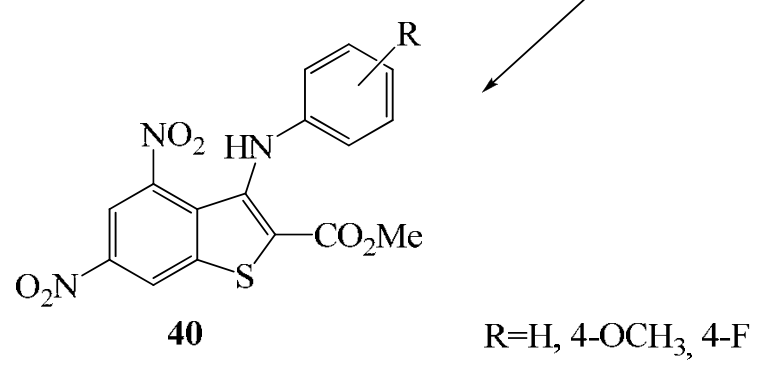

Of interest is that the main cyclization product of azometins $\mathbf{2 0}$ ' is 4,6-dinitrobenzo[b]thiophene-2-methylcarboxylate 41, which is attained in a $40 \%$ yield as a result of the heterocyclic fragment elimination. Expected methyl 3-R-amino-4,6-dinitrobenzo[b]-thiophene-2carboxylate $\mathbf{4 2}$ is produced in minor quantities ( $7 \%$ yield) as a reaction by-product. ${ }^{59}$<smiles>[R]N=Cc1c(SCC(=O)OCC(C)C(C)C)cc([N+](=O)[O-])cc1[N+](=O)[O-]</smiles>

4,6-Dinitrobenzothiophenes can also be sourced from stilbenes 43 where the nitro group is substituted under the action of benzylmercaptan, and the substitution products cyclize to corresponding benzothiophenes under the action of sulfuryl chloride. ${ }^{60,61}$ The $\mathrm{PhCH}_{2}-\mathrm{SAr}$ bond is broken under the action of the chlorinating agent to yield corresponding arylsulfenyl chlorides capable of intramolecular cyclization. If an equimolar amount of sulfuryl chloride is used, 
intermediates 44 are formed. It is curious that the interaction of sulfides 43 with excess of $\mathrm{SO}_{2} \mathrm{Cl}_{2}$ leads to 3-chlorobenzothiophenes $\mathbf{4 5}$.

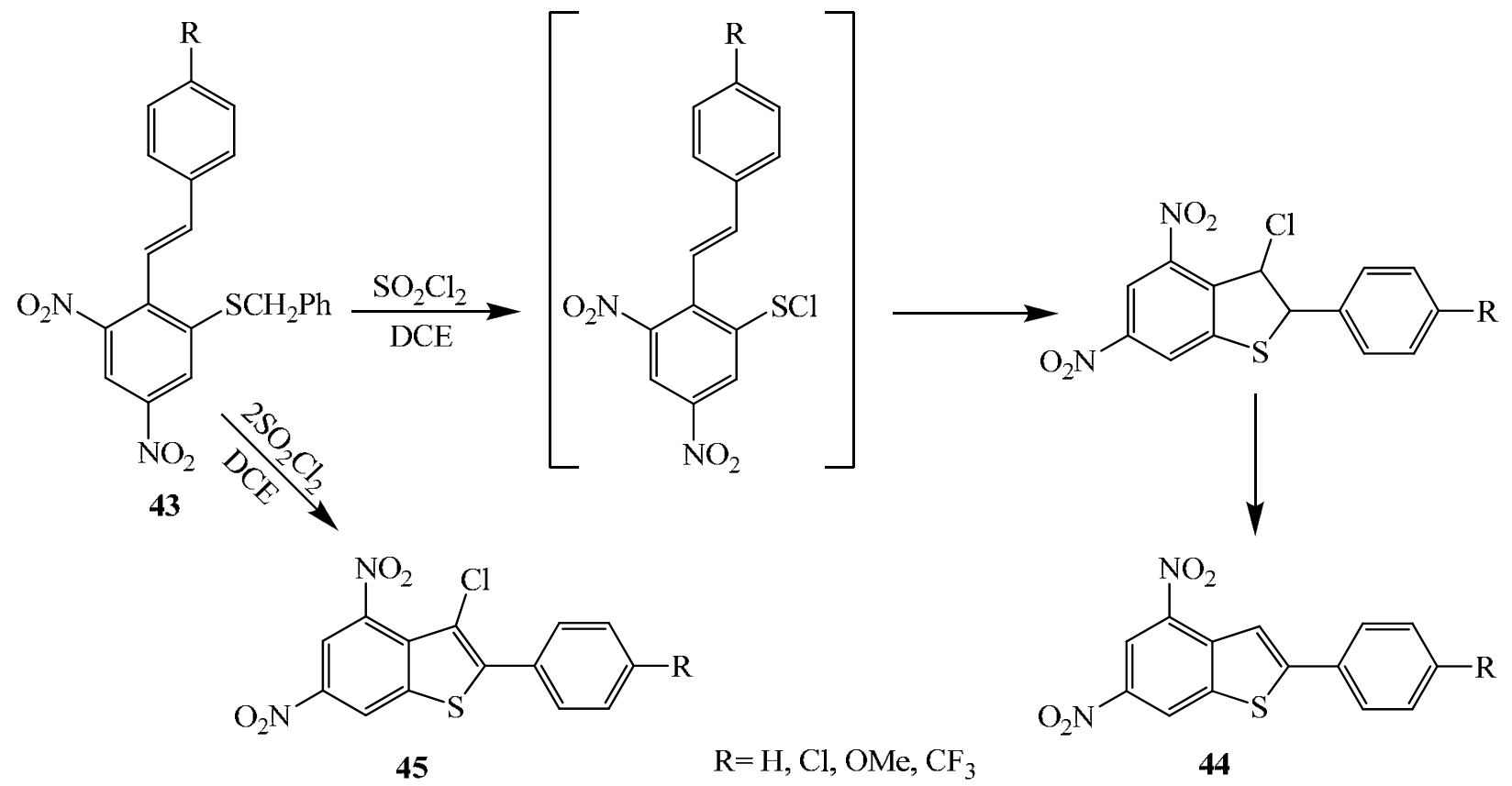

Benzothiophene derivatives can also be prepared on the basis of another TNT derivative trinitrobenzonitrile 18. ${ }^{62}$ The ortho-nitro group in this compound is substituted selectively under the action of the thioglycolic ester. In the reaction conditions, sulfide 18' undergoes intramolecular cyclization resulting in 3-aminobenzothiophene 46. The product yield in this case is $50 \%$. The authors of the other paper ${ }^{63}$ isolated sulfide $\mathbf{1 8}$ ' and exposed it to the MeONa action in methanol. In these conditions, the yield of compound 46 appeared to be higher $(80 \%)$.

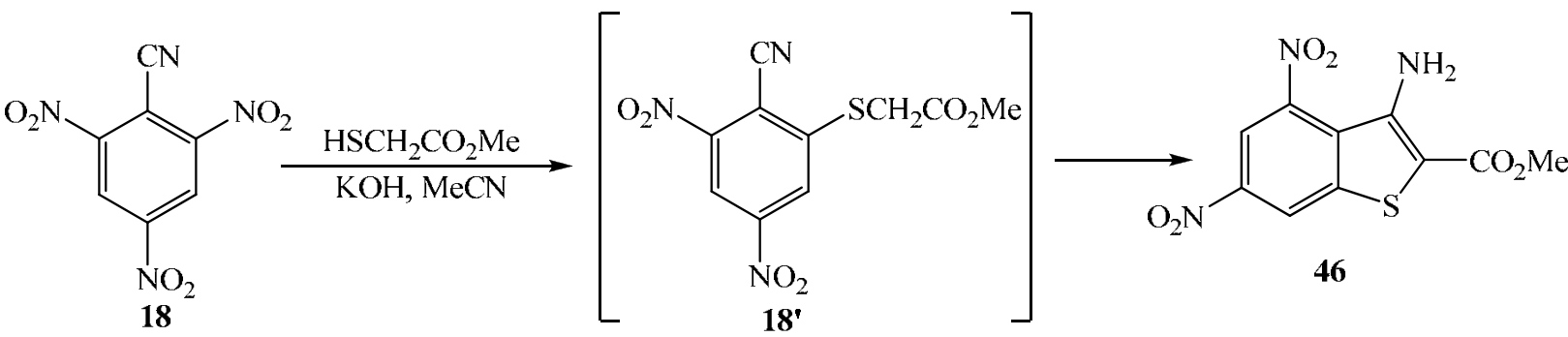

Trinitrobenzamide $\mathbf{3}$ has also been employed in the synthesis of benzannelated heterocycles. ${ }^{64}$ Once amide $\mathbf{3}$ is affected by the ethyl ester of thioglycolic acid, ortho-nitro group substitution and subsequent intramolecular cyclization of sulfide 47 occur to yield 3hydroxybenzothiophene 48. 
<smiles>CCOC(=O)c1sc2cc([N+](=O)[O-])cc([N+](=O)[O-])c2c1O</smiles>

Alcohols 12 prepared by TNT condensation with fluoral and chloral under the action of a base are capable of intramolecular cyclization resulting in dihydrobenzofurans $49 .{ }^{22}$

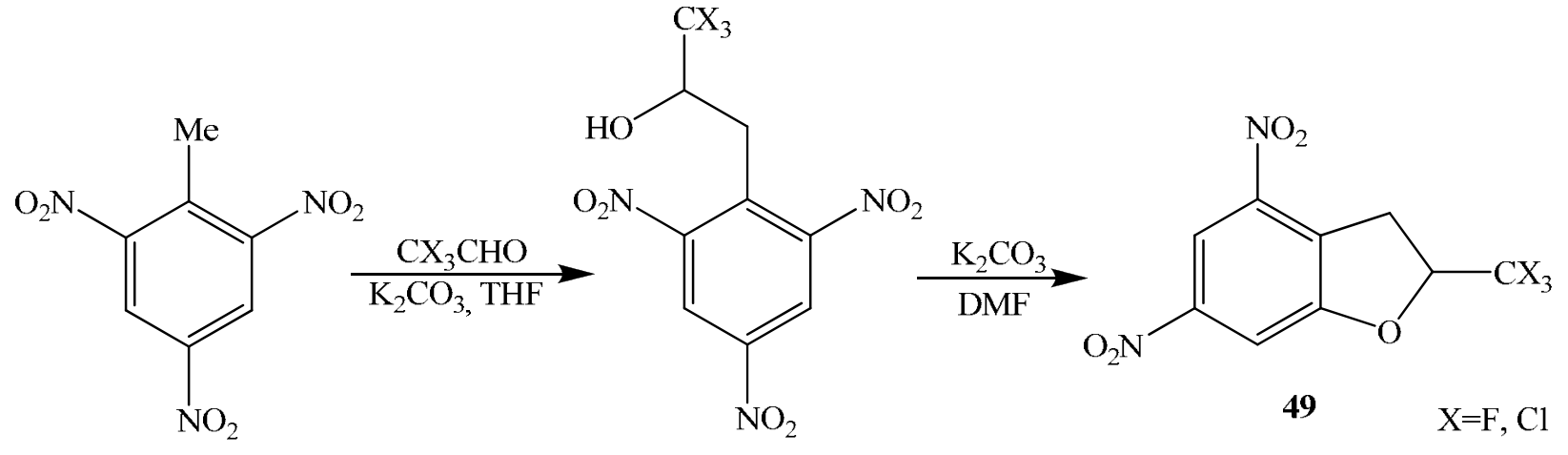
1

12

A TNB-based synthesis of 2-substituted 4,6-dinitro-2,3-dihydrobenzofurans has also been described. ${ }^{9}$ TNB forms anionic adducts with acetone and acetophenone. Their reduction leads to intramolecular cyclization to give 2-substituted 4,6-dinitro-2,3-dihydrobenzofurans 50'. The latter are dehydrogenated in pyridine to yield 2-substituted 4,6-dinitrobenzofurans $\mathbf{5 0 .}$<smiles>[R]c1cc2c([N+](=O)[O-])cc([N+](=O)[O-])cc2o1</smiles>

The ability of trinitrobenzene to substitute its nitro groups under the action of S-, N- and Onucleophiles (such as aryl- and alkylketoximes) is well known. $O$-(3,5-Dinitrophenyl)ketoximes 51 cyclize smoothly yielding 4,6-dinitrobenzofurans 52 substituted in positions 2 and $3 .^{10}$ Cyclization proceeds in the acidic catalysis conditions: heating in $\mathrm{HCl}$ and $\mathrm{CH}_{3} \mathrm{COOH}$ or $\mathrm{H}_{2} \mathrm{SO}_{4}$ and $\mathrm{CH}_{3} \mathrm{COOH}$ mixtures. 
<smiles>[R]CC([R4])=NOc1cc([N+](=O)[O-])cc([N+](=O)[O-])c1</smiles>

6-Amino-4-nitrobenzofurans and 4-hydroxy-6-nitroindoles are formed on heating of the products of selective reduction of oximes 51' [O-(3-amino-5-nitrophenyl)ketoximes] in a mixture of conc. hydrochloric acid and ethanol. ${ }^{11,12}$ The reaction product ratio is $1: 1$; they are separable due to different solubility in the reaction mixture.<smiles>[R]c1c([Al])[nH]c2cc([N+](=O)[O-])cc(O)c12</smiles>

2.3.2. Synthesis of benzannelated five-membered heterocycles with two heteroatoms. A synthesis of 4,6-dinitrobenzo[d]isothiazole derivatives was implemented using a strategy comprising the TNT methyl group transformation, regioselective ortho-nitro group substitution by an appropriate substituent, and cyclization of the synthesized derivative. Another paper describes a synthesis of 2-aryl-4,6-dinitrobenzo[ $d]$ isothiazolium chlorides. ${ }^{65}$ These compounds are obtained through nucleophilic substitution of the ortho-nitro group in $N-(2,4,6-$ trinitrobenzylidene)anilines under the action of benzylmercaptan and the reaction between sulfides $\mathbf{5 4}$ produced thereby and sulfonyl chloride in dichloroethane. 


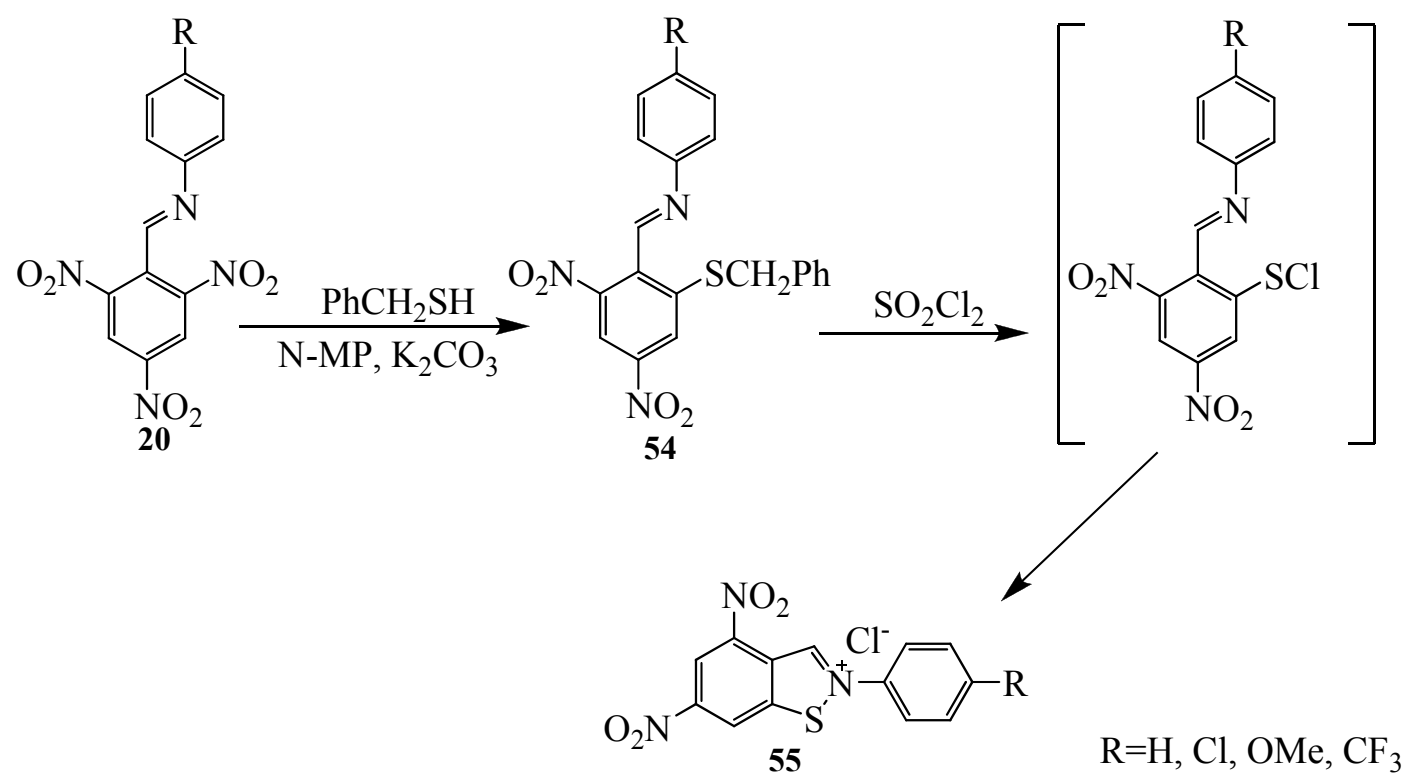

4,6-Dinitrobenzo[ $d]$ isothiazole was synthesized by a similar scheme. ${ }^{66}$ In this case, a starting molecule was the 2,4,6-trinitrobenzaldehyde derivative obtained from ortho-nitro group substitution by benzyl mercaptan. A reaction of sulfide 56 with sulfuryl chloride in DCE leads to the $\mathrm{S}-\mathrm{CH}_{2} \mathrm{Ph}$ bond cleavage and formation of sulfenyl chloride, which, without additional purification, is introduced to a reaction with $20 \%$ ammonia solution in methanol. The only reaction product is 4,6-dinitrobenzo[d]isothiazole 57.<smiles>O=Cc1c([N+](=O)[O-])cc([N+](=O)[O-])cc1[N+](=O)[O-]</smiles>

16<smiles>O=Cc1c([SH+])cc([N+](=O)[O-])cc1[N+](=O)[O-]</smiles>

56<smiles>O=Cc1c(Cl)cc([N+](=O)[O-])cc1[N+](=O)[O-]</smiles><smiles>O=[N+]([O-])c1cc([18O])c2sncc2c1[N+](=O)[O-]</smiles>

Ortho-substituted amides of 2,4,6-trinitrobenzoic acid are also of interest as potential synthons to achieve benzannelated five-membered heterocycles with two heteroatoms, e.g., the literature describes the preparation of 4,6-dinitrobenzo[ $d]$ isothiazolone derivatives from sulfide 58. ${ }^{64,67}$ Sulfenyl chloride is produced after treating compounds $\mathbf{5 8}$ with sulfuryl chloride, which 
then spontaneously cyclizes to 59. Compound $\mathbf{6 0}$ is generated upon the treatment of $\mathbf{5 9}$ with $\mathrm{PCl}_{5}$ or $\mathrm{POCl}_{3}$.

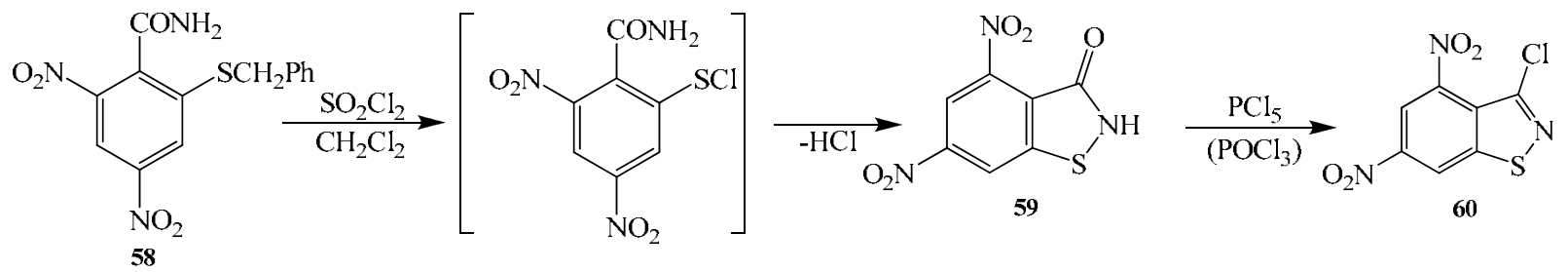

2-Benzylthio-4-nitrobenzamides containing other electron-withdrawing groups react in a similar manner, e.g., 2-benzylthio-6-benzylsulfonyl-4-nitrobenzamide $\mathbf{6 1}$ cyclizes readily to 4benzylsulfonyl-6-nitrobenzo[d]isothiazol-3-one $\mathbf{6 2}$ (84\% yield). ${ }^{67}$

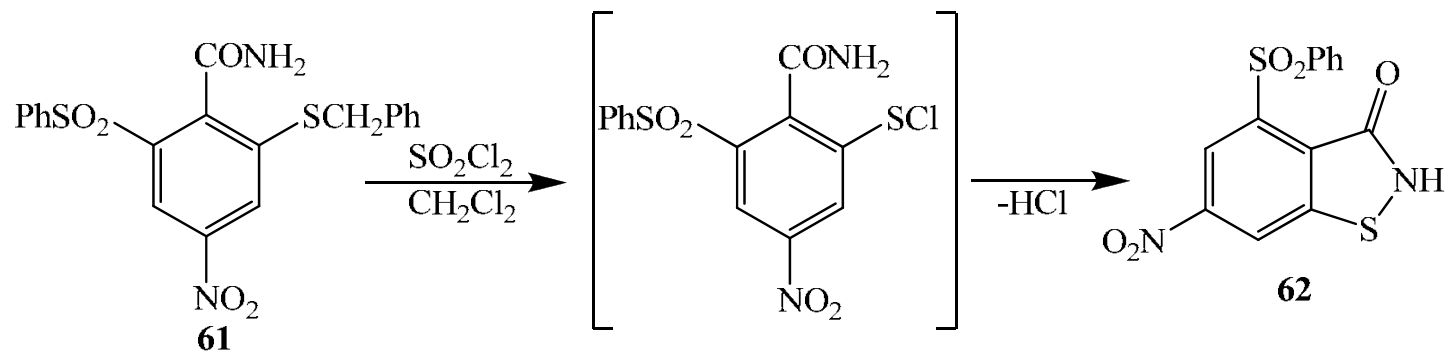

The literature provides data on TNT behaviour under photonitrosation conditions. ${ }^{68}$ The photolysis of TNT water solutions with certain $\mathrm{pH}$ (a nitrite buffer) leads to the trinitrobenzyl anion leading to a number of products, among which 4,6-dinitrobenzo $[d]$ isoxazole 63 was identified.

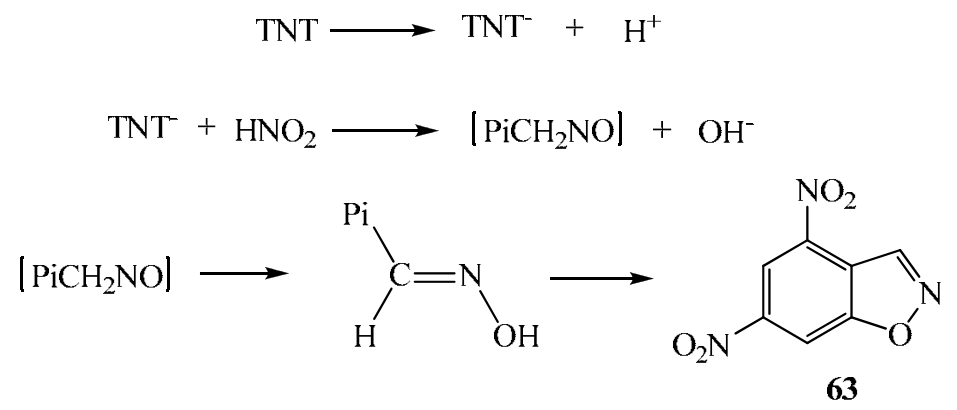

Nitrile of 4,6-dinitrosalicylic acid $\mathbf{6 6}$ is formed under the action of bases on 2-oxyimino-2picrylacetaldehyde. Here the reaction is likely to proceed via a 4,6-dinitro-3formylbenzo[ $[d]$ isoxazole formation step with subsequent simultaneous decarbonylation and isoxazole cycle opening. ${ }^{23,69}$ 
<smiles>N#Cc1c(O)cc([N+](=O)[O-])cc1[N+](=O)[O-]</smiles>

The formyl group protection in oxime $\mathbf{6 4}$ with the formation of respective acetal, hydrazones, $O$-methyloxime, and $N$-phenylamine allows implementing intramolecular nucleophilic substitution of the nitro group resulting in stable benzo[ $d]$ isoxazoles: 3-R-4,6dinitrobenzo $[d]$ isoxazoles 68 are formed on treatment of oximes 67 with $\mathrm{K}_{2} \mathrm{CO}_{3}$ in EtOH. Isoxazoles 68 can be prepared directly from oxime 64 without isolating the intermediates. ${ }^{69}$

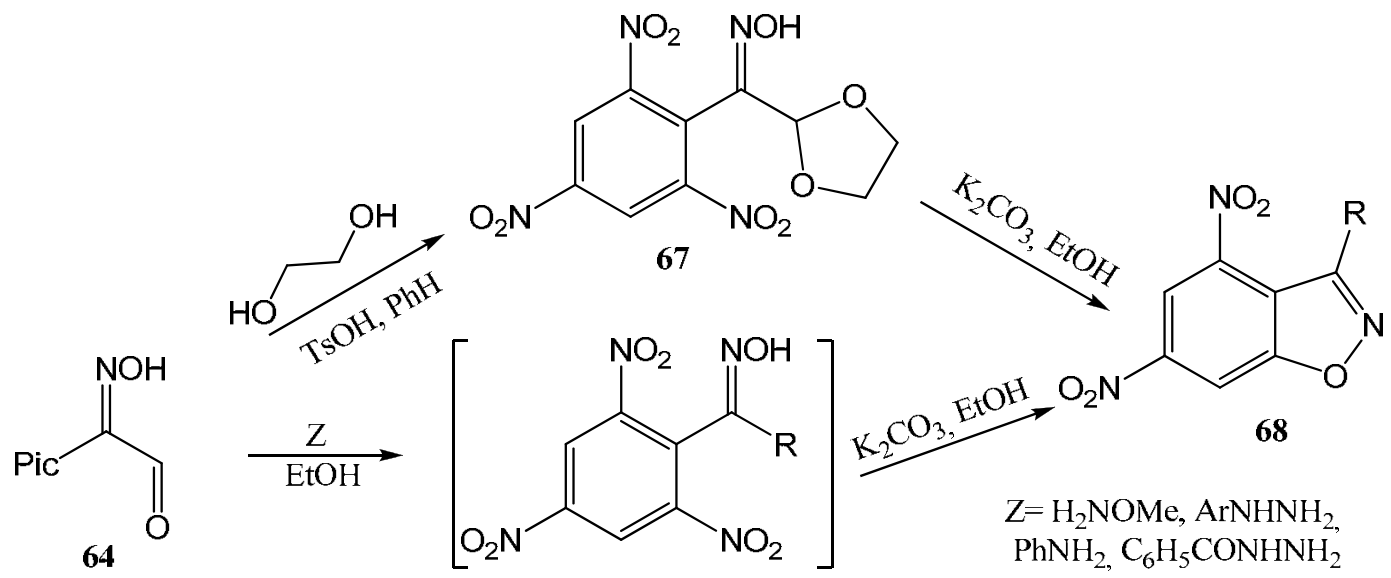

4,6-Dinitroindazole was prepared by diazotization of 2-amino-4,6-dinitrotoluene (a 2,4,6trinitrotoluene partial reduction product). ${ }^{70}$<smiles>CCO[N+](=O)[O-]</smiles>

69<smiles>O=[N+]([O-])c1cc([N+](=O)[O-])c2cn[nH]c2c1</smiles>

70

Along with 4,6-dinitroindazole (according to our data when this methodology is used the final product yield is $\sim 50 \%$ ), 2,4-dinitrotoluene, a diazonium salt reduction product, is attained. A method for the synthesis of 1-aryl(hetaryl)-4,6-dinitro-1H-indazoles based on 2,4,6trinitribenzaldehyde hydrazones is described. ${ }^{26,71,72}$ Hydrazones 71, in the presence of bases, undergo intramolecular cyclization accompanied by nucleophilic substitution of the ortho-nitro group, and indazoles $\mathbf{7 2}$ are produced. 
<smiles>Cn1ncc2c([N+](=O)[O-])cc([N+](=O)[O-])cc21</smiles>

The azo-coupling products (picrylglyoxal monoarylhydrazones) are formed under the action of aryldiazolium salts on picrylacetaldehyde. When hydrazones $\mathbf{7 3}$ are treated with alkali or alkaline metal carbonates, 1-aryl-4,6-dinitro-3-formyl- $1 H$-indazoles $\mathbf{7 4}$ are formed due to intramolecular substitution of the nitro group. ${ }^{73,74}$ When $\mathbf{7 4}$ is treated with hydrochloric hydroxylamine in formic acid, nitrile $\mathbf{7 4 a}$ is obtained.<smiles>[Y]N/N=C(/C=O)c1c([N+](=O)[O-])cc([N+](=O)[O-])cc1[N+](=O)[O-]</smiles>

The methyl ester of 2,4,6-trinitrophenylacetic acid reacts with diazonium salts in a similar way. ${ }^{75}$ Hydrazones $\mathbf{7 5}$ undergo intramolecular cyclization to yield indazoles $\mathbf{7 6}$.<smiles>COC(=O)Cc1c([N+](=O)[O-])cc([N+](=O)[O-])cc1[N+](=O)[O-]</smiles><smiles></smiles>

There are few publications regarding the synthesis of 2-substituted 4,6-dinitro- $2 \mathrm{H}$ indazoles. ${ }^{28,32}$ These researches focus on imines prepared by trinitrobenzaldehyde condensation with aromatic amines. The ortho-nitro groups in compounds $\mathbf{2 0}$ are substituted selectively as affected by sodium azide. The thermolysis of azides 77 in ethylene glycol leads to indazoles $\mathbf{7 8 .}$ 
<smiles>[R]CO[N+](=O)[O-]</smiles>

Meisenheimer complexes formed in TNB reactions with nucleophiles are able to react with the nitro groups present in the molecule under oxidation. In particular, examples of 4,6dinitrobenzo $[c]$ isoxazole formation on TNB interaction with organosilicon compounds in the presence of $\mathrm{KF}$ and 18-crown- 6 with subsequent oxidation of $\mathrm{CCl}_{4} / \mathrm{CuBr}$ are described. ${ }^{76,77}$<smiles>O=[N+]([O-])c1cc([N+](=O)[O-])cc([N+](=O)[O-])c1</smiles><smiles>CCOC(=O)c1onc2cc([N+](=O)[O-])cc([N+](=O)[O-])c12</smiles><smiles>O=[N+]([O-])c1cc([N+](=O)[O-])cc([N+](=O)[O-])c1</smiles>

1.<smiles>C=C(O[SiH2]OC(=O)C1CC1)C1CC1</smiles>
5<smiles>O=C(c1onc2cc([N+](=O)[O-])cc([N+](=O)[O-])c12)C1CC1</smiles>

80

In addition, the literature cites data on the TNT-based preparation of one more representative of this class, i.e. 4,6-dinitrobenzo[c]isoxazole and its derivatives. ${ }^{78-80}$ In particular, this compound was detected as a by-product in irradiation of 2,4,6-trinitrostilbenes $6 .{ }^{80}$ The main products of the stilbene photolysis are derivatives of isatogen $\mathbf{8 2}$.

A synthesis of compound 81, prepared in a low yield by the interaction of 2,4,6trinitrobenzaldehyde with $\mathrm{TiCl}_{3}$, has been reported. ${ }^{80}$

TNT thermal decomposition (during $16 \mathrm{~h}$ at $200^{\circ} \mathrm{C}$ ) has been discussed: ${ }^{79,80}$ among the TNT thermolysis products, the authors isolated and identified 4,6-dinitroanthranyl $\mathbf{8 1}$ and its derivatives . 


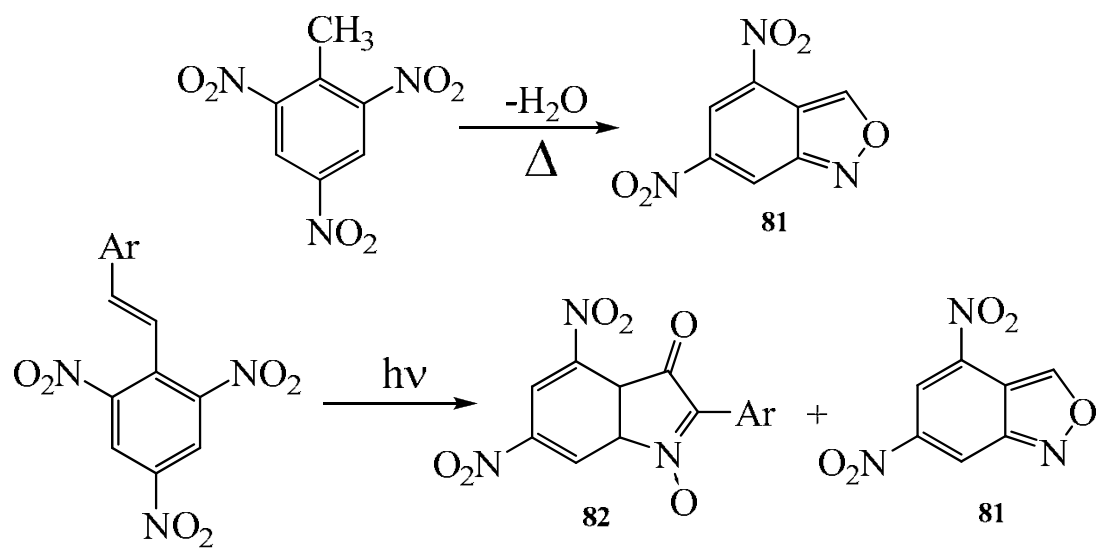

A preparative method for the synthesis of 4,6-dinitrobenzo[c]isoxazole has been developed recently. ${ }^{81}$ As mentioned above, nitrone 15 in the reaction with $\mathrm{NaN}_{3}$ gives azide 83. Compound 83 upon heating under reflux in a toluene- $\mathrm{HCl}$ mixture leads to dinitroanthranyl $\mathbf{8 1}$.

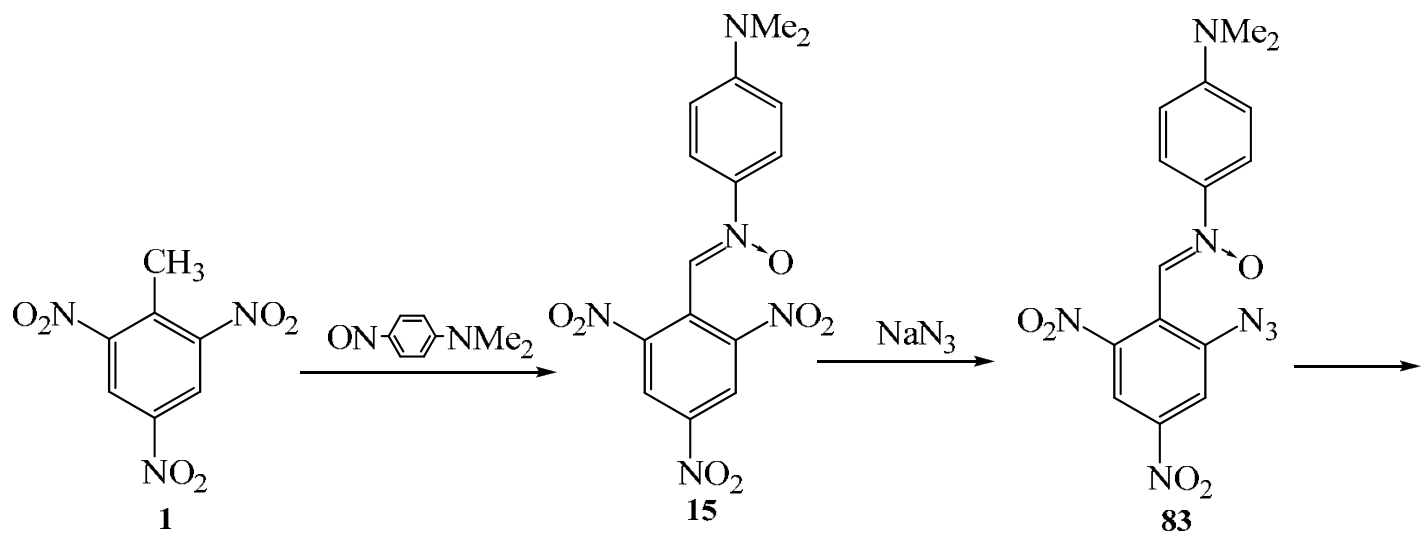

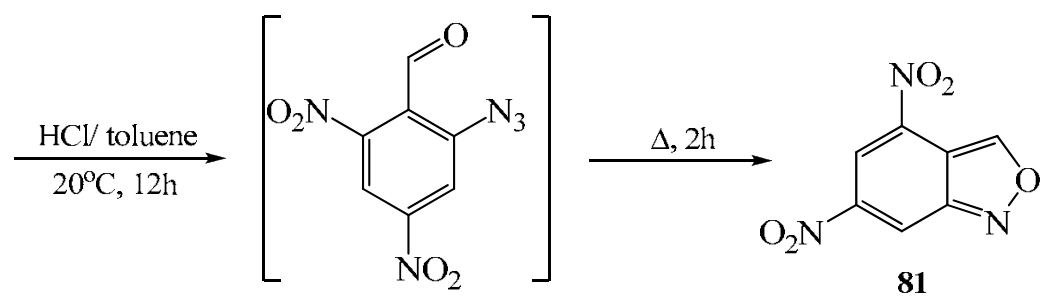

\section{References}

1. Castorina, T. C. In Encyclopedia of explosives and related items, Kaye, S. M., Ed., New Jersey: USA, 1980; Vol. 9, pp 235-298. 
2. Zbarskii, V. L.; Zilin, V. F. Toluene and its nitro derivatives, Moscow: Editorial URSS, 1999, p 214 [in Russian].

3. Terrier, F. Chem. Rev. 1982, 82, 77

4. (a) Montagne, M. P. J. Recl. Trav. Chim. Pays-Bas 1902, 21, 384. (b) Jihane, A.; Mo, X.; Huimin, Z. J. Am. Chem. Soc. 2005, 127, 5332. (c) Sachs, F.; Kempf, R. Chem. Ber. 1902, $35,2712$.

5. Organic Synthesis, Coll. Gilman, H., Ed.; Wiley: N.Y., 1946; Vol.1, p 541, p543.

6. Astrat'ev, A.; Marchukov, V.; Suschev, V.; Aleksandrov, A. $218^{\text {th }}$ American Chemical Society National Meeting, Division of Organic Chemistry, August 1999, Abstract No 50.

7. Zlotin, S. G.; Kislitsin, P. G.; Samet, A. V.; Serebryakov, E. A.; Konyushkin, L. D.; Semenov, V. V.; Buchanan III, A. C.; Gakh, A. A. J. Org. Chem. 2000, 65, 8430.

8. Severin, T.; Schmitz, R.; Temme, H-L. Chem. Ber. 1964, 97, 467.

9. Dutov, M. D.; Vatsadze, I. A.; Vorob'ev, S. S.; Shevelev, S. A. Mendeleev Commun. 2005, 202.

10. Vorob'ev, S. S.; Dutov, M. D.; Vatsadze, I. A.; Kachala, V. V.; Strelenko, Y. A.; Sedov, A. V.; Shevelev, S. A. Mendeleev Commun. 2007, 128.

11. Vorob'ev, S. S.; Dutov, M. D.; Vatsadze, I. A.; Petrosyan, E. P.; Kachala, V. V.; Strelenko, Yu. A.; Shevelev, S. A. Russ. Chem. Bull. Int. Ed. 2007, 5, 1020.

12. Secareanu, S. Bull. Soc. Chim. 1933, 53, 1395.

13. Lelievre, J.; Farrell, V; Terrier, F. J. Chem. Soc., Perkin Trans II 1986, 333.

14. Pfeiffer, P.; Monath, J. Chem. Ber. 1906, 39, 1304.

15. Ullmann, F.; Gschwind, M. Chem. Ber. 1908, 41, 2291.

16. Pfeiffer, P. Chem. Ber. 1915, 48, 1777.

17. Nisbet, H. B. J. Chem. Soc. 1927, 2081.

18. Rozhkov, V. V.; Kuvshinov, A. M.; Gulevskaya, V. I.; Chervin, I. I.; Shevelev, S. A. Synthesis 1999, 12, 2065.

19. (a) Gilbert, E. E. J. Energetic Mater. 1984, 2, 215. (b) Bonecki, Z.; Urbanski, T. Bull. Acad. Pol. Sci., Ser. Chim. 1961, 9, 463.

20. Barba, N. A.; Nedelko, M. S. Zhurn. Organ. Khim. 1983, 19, 1934.

21. Bonecki, Z.; Urbanski, T. Bull. Acad. Pol. Sci., Ser. Chim. 1961, 9, 461.

22. Rozhkov, V. V.; Kuvshinov, A. M.; Shevelev, S. A. Russ. Chem. Bull. Int. Ed. 2000, 3, 573.

23. Vinogradov, V. M.; Dalinger, I. L.; Starosotnikov, A. M.; Shevelev, S. A. Mendeleev Commun. 2000, 140.

24. Sachs, F.; Everding, W. Chem. Ber. 1903, 36, 959.

25. (a) Secareanu, S. Chem. Ber. 1931, 64, 834. (b) Secareanu, S. Chem. Ber. 1931, 64, 836.

26. Starosotnikov, A. M.; Lobach, A. V.; Kachala, V. V.; Shevelev, S.A. Russ. Chem. Bull. Int. Ed. 2004, 3, 584.

27. Mezhnev, V. V.; Dutov, M. D.; Sapozhnikov, O. Yu.; Kachala, V. V.; Shevelev, S. A. Mendeleev Commun. 2007, 234. 
28. Kuvshinov, A. M.; Gulevskaya, V. I.; Rozhkov, V. V.; Shevelev, S. A. Synthesis 2000, 10, 1474.

29. Krohnke, F.; Borner, E. Chem. Ber. 1936, 69, 2006.

30. Krohnke, F. Chem. Ber. 1938, 71, 2583.

31. Tanasescu, I.; Nanu, I. Chem. Ber. 1939, 72, 1083.

32. Brovko, D. A.; Marshalkin, V. N.; Semenov, V. V. Chem.Heterocycl. Comp. 2001, 4, 504.

33. Sitzmann, M. E.; Dacons, J. C. J. Org. Chem. 1973, 38, 4363.

34. Guither, W. D.; Coburn, M. D.; Castle, R. N. Heterocycles 1979, 12, 745.

35. Buncel, M.; Crampton, M. R.; Strauss, M. J.; Terrier, F. Electron deficient aromatic- and heteroaromatic-base interactions. The chemistry of anionic sigma complexes, Elsevier: Amsterdam-Oxford-New York-Tokyo, 1984, p 273.

36. Shevelev, S. A.; Dutov, M. D.; Serushkina, O.V. Russ. Chem. Bull. Int. Ed. 1995, 12, 2424.

37. Serushkina, O. V.; Dutov, M. D.; Shevelev, S. A. Russ. Chem. Bull. Int. Ed. 2001, 2, 261.

38. Benedetti, F.; Marshall, D. R.; Stirling, C. J. M. Chem. Commun. 1982, 918.

39. Shevelev, S. A.; Shakhnes, A. Kh.; Ugrak, B. I.; Vorob'ev, S. S. Synth. Commun. 2001, 31, 2557.

40. Kashaev, V. A.; Hisamutdinov, G. H.; Shevelev, S. A.; Valeshnii, S. I.; Shakhnes, A. Kh.; Bavrina, A. P. Himicheskaya tekhnologiya 2007, 8, 346 [in Russian].

41. Nielsen, T.; Henry, R. A.; Norris, W. P.; Atkins, R. L.; Moore, P. W.; Lepie, A. H. J. Org. Chem. 1979, 44, 2499.

42. Ruggli, P.; Zaeslin, H. Helv. Chim. Acta 1936, 19, 434.

43. Secareanu, S. Bull. Soc. Chim. Fr. 1932, 51, 591.

44. Secareanu, S.; Lupaş, I. J. Prakt. Chem. 1934, 140, 233.

45. Secareanu, S.; Lupaş, I. J. Prakt. Chem. 1934, 140, 90.

46. Secareanu, S. Bull. Soc. Chim. Fr. 1933, 53, 1017.

47. Chernyshev, V. V.; Yatsenko, A. V.; Kuvshinov, A. M.; Shevelev, S. A. J. Appl. Cryst. 2002, 35,669 .

48. Secareanu, S.; Lupaş, I. Bull. Soc. Chim. Fr. 1933, 53, 1436.

49. Secareanu, S.; Lupaş, I. Bull. Soc. Chim. Fr. 1934, 1, 373.

50. Secareanu, S.; Lupaş, I. Bull. Soc. Chim. Fr. 1935, 2, 69.

51. Mezhnev, V. V.; Dutov, M. D.; Shevelev, S. A. Lett. Org. Chem. 2008, 5.

52. Rozhkov, V. V.; Kuvshinov, A. M.; Shevelev, S. A. Synth. Commun. 2002, 32, 1465.

53. Sapozhnikov, O. Yu.; Dyachuk, V. V.; Dutov, M. D.; Kachala, V. V.; Shevelev, S. A. Russ. Chem. Bull. Int. Ed. 2005, 5, 1331.

54. (a) Samet, A.V.; Zakharov, E. P.; Semenov, V. V.; Buchanan, A. C.; Gakh, A. A. Synth. Commun. 2001, 31, 1441. (b) Pullagurla, M.; Siripurapu, U.; Kolanos, R.; Bondarev, M. L.; Dukat, M.; Setola, V.; Roth, B. L.; Glennon, R. A. Bioorg. Med. Chem. Lett. 2005, 15, 5298.

55. Rozhkov, V. V.; Kuvshinov, A. M.; Shevelev, S. A. Org. Prep. Proced. Int. 2000, 32, 94.

56. Eturi, S. R.; Bashir-Hashemi, A.; Iyer, S. U.S. Patent 5969 155, 1999. 
57. Sapozhnikov, O. Yu.; Mezhnev, V. V.; Dutov, M. D.; Shevelev, S. A. Russ. Chem. Bull. Int. Ed. 2005, 4, 1048.

58. Bard, R. R.; Strauss, M. I. J.Org. Chem. 1977, 42, 435.

59. Gulevskaya, V. I.; Kuvshinov, A. M.; Shevelev, S. A. Heterocycl. Commun. 2001 7, 283.

60. Sapozhnikov, O. Yu.; Mezhnev, V. V.; Dutov, M. D.; Kachala, V. V.; Shevelev, S. A. Mendeleev Commun. 2004, 27.

61. Sapozhnikov, O. Yu.; Mezhnev, V. V.; Dutov, M. D.; Kachala, V. V.; Popov, N. A.; Shevelev, S. A. Russ. Chem. Bull. Int. Ed. 2005, 3, 711.

62. Dalinger, I. L.; Cherkasova, T. I.; Khutoretskii, V. M.; Shevelev, S. A. Mendeleev Commun. 2000, 72.

63. Zlotin, S. G.; Kislitsin, P. G.; Kucherov, F. A.; Gakh, A. A. Heterocycles 2006, 68, 1109.

64. Shkinyova, T. K.; Dalinger, I. L.; Molotov, S. I.; Shevelev, S. A. Tetrahedron Lett. 2000, 41, 4973.

65. Sapozhnikov, O. Yu.; Mezhnev, V. V.; Smirnova, E. V.; Kimel, B. G.; Dutov, M. D.; Shevelev, S. A. Mendeleev Commun. 2004, 207.

66. Sapozhnikov, O. Yu.; Smirnova, E. V.; Dutov, M. D.; Kachala, V. V.; Shevelev, S. A. Mendeleev Commun. 2005, 200.

67. Zlotin, S. G.; Kislitsin, P. G.; Podgursky, A. I.; Samet, A. V.; Semenov, V. V.; Buchanan III, A. C.; Gakh, A. A. J. Org. Chem. 2000, 65, 8439.

68. Burlinson, N. E.; Sitzman, M. E.; Kaplan, L. A.; Kayser, E. J. Org. Chem. 1979, 44, 3695.

69. Vinogradov, V. M.; Dalinger, I. L.; Starosotnikov, A. M.; Shevelev, S. A. Russ. Chem. Bull. Int. Ed. 2001, 3, 464.

70. Brand, K.; Eisenmenger, Th. J. Prakt. Chem. 1913, 87, 487.

71. Reich, M. S. Bull. Soc. Chim. Fr. 1917, 111.

72. Reddy, G. Chem. Ind. 1984, 4, 144.

73. Vinogradov, V. V.; Starosotnikov, A. M.; Shevelev, S. A. Mendeleev Commun. 2002, 198.

74. Starosotnikov, A. M.; Kachala, V. V.; Lobach, A. V.; Vinogradov, V. M.; Shevelev, S. A. Russ. Chem. Bull. Int. Ed. 2003, 8, 1782.

75. Rozhkov, V. V.; Vorob'ev, S. S.; Lobach, A. V.; Kuvshinov, A. M.; Shevelev, S. A. Synth. Commun. 2002, 32, 467.

76. Kovalenko, S.V.; Artamkina, G. A.; Terent'ev, P. B.; Shevtsov, P. B.; Beletskaya, I. P.; Reutov, O. A. Chem. Heterocycl.Compd. 1990, 3, 357.

77. Kovalenko, S. V.; Artamkina, G. A.; Beletskaya, I. P.; Reutov, O. A. Russ. Chem. Bull. Int. Ed. 1987, 12, 2668.

78. Dacons, J. C.; Adolph, H. G.; Kamlet, M. J. J. Phys. Chem. 1970, 74, 3035.

79. Oxley, J. C.; Smith, J. L.; Ye, H.; McKenney, R. L.; Bolduc, P. R. J. Phys. Chem. 1970, 99, 9593.

80. Splitter, J. S.; Calvin, M. J. Org. Chem. 1955, $20,1086$.

81. Mezhnev, V. V.; Dutov, M. D.; Shevelev, S. A. Mendeleev Commun. In press. 